\title{
Download
}

UDC 911.9; 502.5 https://doi.org/10.17721/2308-135X.2021.62.55-63

Kalko Andrii Dmitrovich, Doctor Of Geographical Sciences, Professor Internetional university of economics and humanities academician Stepan Demianchuk, Rivne, Ukraine, e-mail: edissey@meta.ua

Melniychuk Michaylo Michaylovich, candidate of geographical sciences, associate professor Lesya Ukrainka Eastern European National University, Luck, Ukraine

Uevich Sergii Dmitrovich, candidate of geographical sciences Lesya Ukrainka Eastern European National University, Luck, Ukraine

Kalenikov Bogdan Ivanovich Polissya National University, Zhytomyr, Ukraine

\section{ANALYSIS OF TRANSFORMATION OF WATER AND LAND RESOURCES UNDER THE INFLUENCE OF DRAINAGE RECLAMATION IN VOLYN REGION}

Aim. The purpose of this study is to develop a methodology that takes into account the levels of anthropogenic transformation of various components of the environment.

Method. In scientific work to take into account the impact of qualitative indicators on the process of transformation of landscapes of Volyn region under the influence of drainage reclamation was used P. Shishchenko's method with the following additions: the coefficient of anthropogenic transformation of landscapes was calculated separately for: relief and soils and water regime. 
Results. Understanding the state of lands transformed in the process of drainage reclamation provides an opportunity to understand the effects of a complex of factors on land and agricultural needs and encourages scientific study of various components of the environment. During drainage reclamation there is an intensive mineralization of the organic part of the soil with a significant increase in greenhouse gas emissions and the processes of peat mineralization are actively developing. The total coefficient of anthropogenic transformation of landscapes was defined as the average value between these coefficients. The results obtained by an improved method allow a more differentiated assessment of the state of transformation of the landscapes of the Volyn region, taking into account the impact of drainage reclamation. These results are adequate, as there is a connection with the industrial development of territories and the level of agricultural development.

The scientific novelty lies in the constructive-geographical analysis of the impact of drainage reclamation in the Volyn region on different types of environment.

Practical significance. The results of the research can be used in the educational process of VSU named after Lesya Ukrainka and other educational institutions in teaching geographical, economic and tourism disciplines. The results will find their application in the legislative and executive work of local governments in the development of programs of socio-economic development of territorial communities. The materials of the research will promote the rational use of anthropogenic resources and objects of social and household services in Volyn, which will allow to qualitatively influence the course of administrative reform. A number of provisions can be used in similar studies of the regions of Ukraine.

Key words: reclamation, drainage, transformation, soil, environment.

References

1. Ryzhuk S. M., Slyusar I. T., Vergunov V. A. Agroecological features of highly efficient use of drained peat soils of polissya and forest-steppe: monograph. K.: Agricultural science, 2002. 137 c. 
2. Gerenchuk K. I. Nature of the Volyn region. Lviv: Higher school. 1981. 147 p.

3. Uevych S. D. Features of reclamation works in Ratnivshchyna. Young science of Volyn: priorities and prospects of research: materials of the VII International scientific-practical conference of students and graduate students (May, 2013): in 2 volumes. SNU Lesya Ukrainka, 2013. P. 121-122.

4. Zuzuk F. V., Koloshko L. K., Karpyuk Z. K. Drained lands of Volyn region and their protection: monograph. Lutsk: University Lesya Ukrainka, 2012. 294 p.

5. Shevchuk M. Y., Zinchuk P. Y., Koloshko L. K. Soils of the Volyn region. Lutsk: RVV "Vezha" VSU Lesya Ukrainka, 1999. 160 p.

6. Shishchenko P. G. Applied physical geography. K .: Higher school, 1988. 192 p.

7. Koinova I. B. Anthropogenic transformation of landscape systems of the western part of Volyn Polissya: author's ref. dis ... cand. geogr. Sciences: 11.00.11 / I. B. Koinova; Lviv. state Univ. I. Franko. L., 1999. 19 p.

8. Polyansky S. V. Constructive-geographical analysis and assessment of the state of reclaimed agro-landscapes of Volyn region: author's ref. dis ... cand. geogr. Sciences: 11.00.11 / Sergey Vladimirovich Polyansky. Lviv, 2013. 20 p.

9. Prikhodko M. M. Ecological safety of natural and anthropogenically modified geosystems: monograph. Ivano-Frankivsk: Foliant, 2013. 330 p. 